\title{
Who's Afraid of Unenumerated Rights?
}

Randy E. Barnett

Georgetown University Law Center, rb325@law.georgetown.edu

Georgetown Public Law and Legal Theory Research Paper No. 880715

This paper can be downloaded free of charge from:

https://scholarship.law.georgetown.edu/facpub/840

http://ssrn.com/abstract $=880715$

9 U. Pa. J. Const. L. 1-22 (2006)

This open-access article is brought to you by the Georgetown Law Library. Posted with permission of the author. Follow this and additional works at: https://scholarship.law.georgetown.edu/facpub

Part of the Constitutional Law Commons, and the Judges Commons 


\section{ARTICLES \\ WHO'S AFRAID OF UNENUMERATED RIGHTS?}

\section{Randy E. Barnett}

As most scholars today would acknowledge, there are not one but two distinct unenumerated rights provisions mentioned in the text of the Constitution: the Ninth Amendment's injunction that "The enumeration in the Constitution, of certain rights, shall not be construed to deny or disparage others retained by the people," and the Privileges or Immunities Clause of the Fourteenth Amendment's command that, "No State shall make or enforce any law which shall abridge the privileges or immunities of citizens of the United States ...." For nearly twenty years now, I have been defending the proposition that the original meaning of the Ninth Amendment limits federal power. ${ }^{3}$ Meanwhile Michael Kent Curtis almost singlehandedly reversed the conventional wisdom about the original meaning of the Privileges or Immunities Clause, which now, most admit, protects unenumerated rights (along with rights from the Bill of Rights) from interference by the states.

In this essay, I will not examine the evidence of original meaning that supports this reading of these two clauses. Instead, I propose to take up the next most challenging topics, once one concedes this original meaning: Why have these two clauses been ignored by courts for most of their lengthy histories, and how can they be put into effect in a practical fashion? Answering the first of these question is essential to answering the second. In my view, there is not just one but several reasons why two expressed provisions have been redacted

\footnotetext{
" Carmack Waterhouse Professor of Legal Theory, Georgetown University Law Center. This paper was prepared for the University of Pennsylvanian Journal of Constitutional Law Symposium on "The Future of Unenumerated Rights," University of Pennsylvania Law School, February 10, 2006.

${ }^{1}$ U.S. CONST. amend. IX.

${ }^{2}$ Id. amend. XIV.

${ }^{3}$ See, e.g., Randy E. Barnett, The Ninth Amendment: It Means What It Says, 85 Tex. L. Rev. (forthcoming Nov. 2006) (explaining the author's view of the Ninth Amendment); Randy E. Barnett, Reconceiving the Ninth Amendment, 74 CORNELL L. REV. 1 (1988) (arguing for the original meaning of the Ninth Amendment).

${ }^{4}$ See generally Michael Kent Curtis, No State Shall Abridge: The Fourteenth AMENDMENT AND THE BILL OF RIGHTS (1986).
} 
from our written Constitution. To restore these portions of the Constitution requires that we identify the reasons why they were lost.

\section{EARLY RESERVATIONS ABOUT UNENUMERATED RIGHTS}

While some may think that the Ninth Amendment was lost from the very beginning, others know better. In the first Congress, Representative James Madison invoked the Ninth Amendment in his famous speech opposing the constitutionality of the Bank of the United States. There he affirmed: "The latitude of interpretation required by the bill is condemned by the rule furnished by the Constitution itself." As one authority for this "rule" of interpretation, Madison cited the Ninth Amendment:

The explanatory amendments proposed by Congress themselves, at least, would be good authority with them; all these renunciations of power proceeded on a rule of construction, excluding the latitude now contended for.... He read several of the articles proposed, remarking particularly on the 11th [the Ninth Amendment] and 12th [the Tenth Amendment], the former, as guarding against a latitude of interpretation; the latter, as excluding every source or power not within the Constitution itself. $^{6}$

Some ten years later, Virginia jurist and scholar St. George Tucker, offered a similar federal power-constraining construction of the Ninth Amendment:

All the powers of the federal government being either expressly enumerated, or necessary and proper to the execution of some enumerated power; and it being one of the rules of construction which sound reason has adopted; that, as exception strengthens the force of a law in cases not excepted, so enumeration weakens it, in cases not enumerated; it follows, as a regular consequence, that every power which concerns the right of the citizen, must be construed strictly, where it may operate to infringe or impair his liberty; and liberally, and for his benefit, where it may operate to his security and happiness, the avowed object of the constitution ....?

This passage concerning the individual rights of citizens is immediately followed by and distinguished from Tucker's assertion of states rights:

[A]nd, in like manner, every power which has been carved out of the states, who, at the time of entering into the confederacy, were in full possession of all the rights of sovereignty, is in like manner to be construed strictly,

\footnotetext{
${ }^{5} 2$ ANNAls OF CONG. 1949 (1791) (emphasis added).

${ }^{6} I d$. at 1951 (The Eleventh and Twelfth proposed amendments that Madison referenced were eventually adopted as the Ninth and Tenth Amendments) (emphasis added).

${ }^{7}$ William Blackstone, 1 Commentaries: With Notes of Reference to the CoNSTITUTION AND LAWS OF THE FEderal GOVERnMENT OF THE United STATES; AND OF THE COMMONWEALth OF ViRginia app. at 307-08 (St. George Tucker ed., 1803) (emphasis added).
} 
wherever a different construction might derogate from the rights and powers, which by the latter of these articles; are expressly acknowledged to be reserved to them respectively. ${ }^{8}$

This distinction between the individual and personal nature of the rights retained by the people, and the rights of states is also made explicit in another passage from Tucker: "As federal it is to be construed strictly, in all cases where the antecedent rights of a state may be drawn in question ...." This sentence includes a footnote citing the Tenth (Twelfth) Amendment. The passage then continues:

$[A]$ s a social compact it ought likewise to receive the same strict construction, wherever the right of personal liberty, of personal security, or of private property may become the subject of dispute; because every person whose liberty or property was thereby rendered subject to the new government, was antecedently a member of a civil society to whose regulations he had submitted himself, and under whose authority and protection he still remains, in all cases not expressly submitted to the new government. ${ }^{10}$

This passage is followed by a footnote reference to the Ninth (Eleventh) and Tenth (Twelfth) Amendments.

Despite this original public meaning of the Ninth Amendment, courts have been reluctant to explicitly protect unenumerated rights. In Calder v. Bull, decided between Madison and Tucker's invocation of the Ninth Amendment, we see Justice Chase famously affirming the potential unconstitutionality of laws that violate unenumerated rights. His argument is worth reproducing at length:

I cannot subscribe to the omnipotence of a State Legislature, or that it is absolute and without control; although its authority should not be expressly restrained by the Constitution, or fundamental law, of the State. The people of the United States erected their Constitutions, or forms of government, to establish justice, to promote the general welfare, to secure the blessings of liberty; and to protect their persons and property from violence. The purposes for which men enter into society will determine the nature and terms of the social compact; and as they are the foundation of the legislative power, they will decide what are the proper objects of it: The nature, and ends of legislative power will limit the exercise of it. This fundamental principle flows from the very nature of our free Republican governments, that no man should be compelled to do what the laws do not require; nor to refrain from acts which the laws permit. There are acts which the Federal, or State, Legislature cannot do, without exceeding their authority. There are certain vital principles in our free Republican governments, which will determine and over-rule an apparent and flagrant abuse of legislative power; as to authorize manifest injustice by positive law; or to take away that security for personal liberty, or private property, for the protection whereof the government was established. An ACT of the Legislature (for I cannot call it a

\footnotetext{
${ }^{8}$ Id. at 308 (emphasis added).

${ }^{9} I d$. at 151 (internal citation omitted).

${ }^{10} I d$. (emphasis added).
} 
law) contrary to the great first principles of the social compact, cannot be considered a rightful exercise of legislative authority.

Chase's view of unenumerated rights fits completely with that of Madison and Tucker, though this being an exercise of state power, the Ninth Amendment's affirmation of limited federal power was not pertinent to the question before the Court.

In contrast with Chase, we have Justice Iredell's almost-equallyfamous concurring opinion denying the legal force of unenumerated limits on legislative power:

If, then, a government, composed of Legislative, Executive and Judicial departments, were established, by a Constitution, which imposed no limits on the legislative power, the consequence would inevitably be, that whatever the legislative power chose to enact, would be lawfully enacted, and the judicial power could never interpose to pronounce it void. It is true, that some speculative jurists have held, that a legislative act against natural justice must, in itself, be void; but I cannot think that, under such a government, any Court of Justice would possess a power to declare it so.

... If, on the other hand, the Legislature of the Union, or the Legislature of any member of the Union, shall pass a law, within the general scope of their constitutional power, the Court cannot pronounce it to be void, merely because it is, in their judgment, contrary to the principles of natural justice. The ideas of natural justice are regulated by no fixed standard: the ablest and the purest men have differed upon the subject; and all that the Court could properly say, in such an event, would be, that the Legislature (possessed of an equal right of opinion) had passed an act which, in the opinion of the judges, was inconsistent with the abstract principles of natural justice. ${ }^{12}$

One reason why I find Justice Iredell's denial in Calder both interesting and disturbing is how it contrasts with his colorful affirmation of unenumerated rights before the North Carolina ratification convention ten years earlier. To those who urged the Constitution be rejected because it lacked a bill of rights, he replied:

[I] t would not only be useless, but dangerous, to enumerate a number of rights which are not intended to be given up; because it would be implying, in the strongest manner, that every right not included in the exception might be impaired by the government without usurpation; and it would be impossible to enumerate every one. Let any one make what collection or enumeration of rights he pleases, I will immediately mention twenty or thirty more rights not contained in it. ${ }^{13}$

By opposing the enactment of a bill of rights on this ground, Iredell is here contending that all rights should remain unenumerated. He

\footnotetext{
${ }^{11}$ Calder v. Bull, 3 U.S. (3 Dall.) 386, 387-88 (1798).

${ }^{12}$ Id. at 398-99 (Iredell, J., concurring).

${ }^{13} 4$ The Debates in the SeVeral State Conventions on the Adoption of the Federal CONSTITUTION 167 (Jonathan Elliot ed., 2d ed. 1861) [hereinafter DEBATES].
} 
further contends that impairing such unenumerated rights would be a usurpation Nowhere in this speech does he suggest that only enumerated limitations on legislative power would be enforceable, as he later did in Calder. ${ }^{14}$ (Imagine the effect of his argument on the North Carolina debate if he had!)

One or the other of these claims by Iredell cast him in a poor light. At the North Carolina convention, he could have been concealing his skepticism about the effectiveness of unenumerated rights in service of his opposition to a bill of rights that would expressly limit federal power. Or in Calder, he could have been concealing his belief that violations of unenumerated rights are usurpations in favor of assertions of state and federal legislative power. Of course, he could also have simply changed his mind.

It will not do to reconcile Iredell's apparent inconsistency by claiming he was speaking in Calder only of the propriety of judicial review, and that he could well have believed that legislative violations of unenumerated rights were usurpations, while maintaining it was not a matter for courts to resolve. While it is likely he did believe this, it would still not justify his earlier opposition to the very sorts of express restrictions on federal power that were being urged by AntiFederalists. The most charitable account of Iredell's opposition is that the Anti-Federalists themselves were more interested in defeating the Constitution than gaining a bill of rights, and Federalists like Iredell were more interested in securing ratification against AntiFederalist objections. Neither side cared much about a bill of rights.

Be this is as it may, it was Justice Iredell's stance on unenumerated limits on legislative power expressed in Calder, not Justice Chase's, that came to be the dominant treatment of unenumerated rights: that they were not a matter for judicial protection. I now turn to the issue of why.

\section{THE POSITIVIST TURN}

As reflected in Iredell's concurrence, early in our legal history judges made a decided turn away from natural rights as a basis of limiting legislative power and towards a positivist approach that enforced whatever laws did not violated express prohibitions. By "positivism," I

\footnotetext{
${ }^{14}$ Calder, 3 U.S. (3 Dall.) at 399 (Iredell, J., concurring) ("In order, therefore, to guard against so great an evil, it has been the policy of all the American states, which have, individually, framed their state constitutions since the revolution, and of the people of the United States, when they framed the Federal Constitution, to define with precision the objects of the legislative power, and to restrain its exercise within marked and settled boundaries. If any act of Congress, or of the Legislature of a state, violates those constitutional provisions, it is unquestionably void; though, I admit, that as the authority to declare it void is of a delicate and awful nature, the Court will never resort to that authority, but in a clear and urgent case.")
} 
simply mean that statutes enacted by popularly-elected legislatures are laws binding on judges, unless they violate an express prohibition in a popularly-enacted constitution. Persons holding such a view could well acknowledge the existence of natural rights by which the prudence or morality of laws could be assessed, while denying, as Iredell did, the pertinence of this inquiry to constitutional adjudication.

I do not intend to make a strong historical claim about how and why this shift took place. Such an inquiry would necessitate a far more extensive treatment of historical context than the evidence of linguistic usage that is required by original meaning originalism. That some such shift took place, however, is widely acknowledged. The positivist turn was manifested in at least two contexts.

The first was the embrace of Blackstone by American lawyers. This is evidenced by Iredell's concurrence itself, in which he cites Blackstone:

Sir William Blackstone, having put the strong case of an act of Parliament, which should authorise a man to try his own cause, explicitly adds, that even in that case, "there is no court that has power to defeat the intent of the Legislature, when couched in such evident and express words, as leave no doubt whether it was the intent of the Legislature, or no."

It is precisely because Iredell apparently accepts this background principle of legislative supremacy that he asserts the need for express prohibitions on legislative power "to guard against so great an evil" as complete legislative authority of the sort possessed by Parliament. ${ }^{16}$

While some point to Blackstone's early popularity among American lawyers to show that natural rights were never considered justiciable, the evidence-including Chase's opinion in Calder-suggests otherwise. So too does founder and Justice James Wilson's condemnation in Chisholm v. Georgia of the unhealthy influence of Blackstone's view of sovereignty:

This last position is only a branch of a much more extensive principle, on which a plan of systematic despotism has been lately formed in England, and prosecuted with unwearied assiduity and care. Of this plan the author of the Commentaries was, if not the introducer, at least the great supporter. He has been followed in it by writers later and less known; and his doctrines have, both on the other and this side of the Atlantic, been implicitly and generally received by those, who neither examined their principles nor their consequences. The principle is, that all human law must be prescribed by a superior. This principle I mean not now to examine. Suffice it, at present to say, that another principle, very different in its nature and operations, forms, in my judgment, the basis of sound and genuine jurisprudence; laws derived from the pure source of equality and justice must be founded on the CONSENT of those, whose obedience

\footnotetext{
${ }^{15}$ Id. at 398-99 (citing William Blackstone, 2 Commentaries *91).

${ }^{16} I d$. at 399.
} 
they require. The sovereign, when traced to his source, must be found in the man.

Like the other founders, Wilson denied that "sovereignty" resides in the government as opposed to the people:

To the Constitution of the United States, the term SOVEREIGN, is totally unknown. There is but one place where it could have been used with propriety. But, even in that place it would not, perhaps, have comported with the delicacy of those, who ordained and established that Constitution. They might have announced themselves "SOVEREIGN" people of the United States: But serenely conscious of the fact, they avoided the ostentatious declaration.

Wilson then adds, "As the State has claimed precedence of the people; so, in the same inverted course of things, the Government has often claimed precedence of the State; and to this perversion in the second degree, many of the volumes of confusion concerning sovereignty owe their existence." 19

By contrast, it is revealing that we find Iredell once again on the other side of this debate. In his opinion in Chisholm, he strongly asserts the concept of state sovereignty:

Every State in the Union in every instance where its sovereignty has not been delegated to the United States, I consider to be as completely sovereign, as the United States are in respect to the powers surrendered. The United States are sovereign as to all the powers of Government actually surrendered: Each State in the Union is sovereign as to all the powers reserved. $^{20}$

Iredell questions the extent of federal judges' authority to enforce the Constitution without an authorization by Congress:

My conception of the Constitution is entirely different. I conceive, that all the courts of the United States must receive, not merely their organization as to the number of Judges of which they are to consist; but all their authority, as to the manner of their proceeding, from the Legislature only. This appears to me to be one of those cases, with many others, in which an article of the Constitution cannot be effectuated without the intervention of the Legislative authority. ${ }^{21}$

To this proposition he admits of only one exception that presages his stance in Calder: if Congress exceeds its express authority under the Constitution, its law is null and void.

If they do, I have no hesitation to say, that any act to that effect would be utterly void, because it would be inconsistent with the Constitution, which is a fundamental law paramount to all others, which we are not

\footnotetext{
${ }^{17}$ Chisholm v. Georgia, 2 U.S. (2 Dall.) 419, 458 (1793) (Wilson, J., concurring).

${ }^{18} I d$. at 454.

${ }^{19} \mathrm{Id}$. at 455

${ }^{20} I d$. at 435 (majority opinion).

${ }^{21} I d$. at 432.
} 
only bound to consult, but sworn to observe; and, therefore, where there is an interference, being superior in obligation to the other, we must unquestionably obey that in preference. ${ }^{22}$

So here, as in Calder, according to Iredell, the only restrictions on the powers of Congress that are to be enforced by the courts are those expressed in the Constitution.

The decided shift to Blackstonian theory in America was noted by Thomas Jefferson who commented in 1814:

I join in your reprobation of our merchants, priests, and lawyers, for their adherence to England and monarchy, in preference to their own country and its Constitution.... With the lawyers it is a new thing. They have, in the Mother country, been generally the firmest supporters of the free principles of their constitution. But there too they have changed. I ascribe much of this to the substitution of Blackstone for my Lord Coke, as an elementary work. In truth, Blackstone and Hume have made tories of all England, and are making tories of those young Americans whose native feelings of independence do not place them above the wily sophistries of a Hume or a Blackstone. These two books, but especially the former, have done more towards the suppression of the liberties of man, than all the million of men in arms of Bonaparte and the millions of human lives with the sacrifice of which he will stand loaded before the judgment seat of his Maker. I fear nothing for our liberty from the assaults of force; but I have seen and felt much, and fear more from English books, English prejudices, English manners, and the apes, the dupes, and designs among our professional crafts. ${ }^{23}$

In his 1820 book condemning the reasoning of McCulloch $v$. Maryland, fellow Virginian John Taylor began by lambasting the growing use of the concept of "sovereignty" underlying Blackstonian positivism.

I do not know how it has happened, that this word has crept into our political dialect, unless it be that mankind prefer mystery to knowledge; and that governments love obscurity better than specification... .

Neither the declaration of independence, nor the federal constitution, nor the constitution of any single state, uses this equivocal and illimitable word. $^{24}$

Taylor explains why, in a system such as that of the United States, the concept of sovereignty is deeply confused:

The idea of investing servants with sovereignty, and that of investing ourselves with a sovereignty over other nations, were equally preposterous. Sovereignty implies superiority and subordination. It was therefore inapplicable to a case of equality, and more so to the subordinate power in

\footnotetext{
${ }^{22} I d$. at 433.

${ }^{23}$ Letter from Thomas Jefferson to Horatio Gates Spafford (Mar. 17, 1814), in 14 THE WRITINGS OF THOMAS JEFFERSON 118, 119-20 (Andrew A. Lipscomb ed., Mem'l ed. 1904).

${ }^{24}$ JOHN TAYLOR, CONSTRUCTION CONSTRUED, AND CONSTITUTIONS VindiCATED 25 (1820).
} 
reference to its creator. The word being rejected by our constitutions, cannot be correctly adopted for their construction; because, if this unanimous rejection arose from its unfitness for their design of defining and limiting powers, its interpolation by construction for the purpose of extending these same powers, would be an evident inconsistency. It would produce several very obvious contradictions in our political principles. It would transfer sovereignty from the people, (confining it to mean the right of self-government only,) to their own servants. It would invest governments and departments, invested with limited powers only, with unspecified powers. It would create many sovereignties, each having a right to determine the extent of its sovereignty by its own will. And if two sovereignties over the same subjects could never agree, it would propose for our consideration what was to be expected from an army of sovereignties. Our constitutions, therefore, wisely rejected this indefinite word as a traitor of civil rights, and endeavored to kill it dead by specifications and restrictions of power, that it might never again be used in political disquisitions. ${ }^{25}$

Nevertheless, the notion that sovereignty resided in the state and federal legislatures took hold, as did the notion expressed by Iredell that the only restrictions on that power of which courts may take notice are those expressly stipulated in the Constitution. With this as a conceptual foundation, there is little or no room for unenumerated rights restricting the powers of the legislature.

The second manifestation of the positivist turn among the judiciary concerned the legality of slavery. As was poignantly described by Robert Cover in Justice Accused, ${ }^{26}$ even abolition-inclined judges asserted the proposition that the positive law of Congress trumped any considerations of natural justice, as did the positive law of the Constitution itself. The divide between natural rights constraints on legislative power and a positivistic respect for legislative supremacy is wellillustrated by the lengthy and impassioned debate in the 1840s between radical abolitionists Lysander Spooner and Wendell Phillips.

While Spooner conceded that the positive law violating natural rights could be enforceable, he contended that constitutional meaning should not be construed as violating natural rights unless expressed with unmistakable clearness. Spooner based his approach to constitutional construction on John Marshall's maxim of statutory construction: "Where rights are infringed, where fundamental principles are overthrown, where the general system of the laws is departed from, the legislative intention must be expressed with irresistible clearness to induce a court of justice to suppose a design to effect

\footnotetext{
${ }^{25} I d$. at 26.

${ }^{26}$ See Robert M. Cover, Justice Accused: Antislavery and the Judicial Process 60 (1975) (noting how judges were unwilling to engage in an open-ended exploration of the natural rights of slaves unless explicitly authorized by positive law).
} 
such objects." ${ }^{27}$ Spooner applied Marshall's version of a "clear statement rule" to the Constitution itself:

1st, that no intention, in violation of natural justice and natural right ... can be ascribed to the constitution, unless that intention be expressed in terms that are legally competent to express such an intention; and $2 \mathrm{~d}$, that no terms, except those that are plenary, express, explicit, distinct, unequivocal, and to which no other meaning can be given, are legally competent to authorize or sanction anything contrary to natural right.

As did St. George Tucker, Spooner contended that "all language must be construed 'strictly' in favor of natural right." ${ }^{29}$ In essence, like Tucker, Spooner adopted what I have called, a "presumption of liberty."

In contrast, fellow abolitionist Wendell Phillips, a close ally of William Lloyd Garrison, hotly rejected Spooner's natural law approach in favor of a strongly majoritarian version of Austinian positivism:

There can be no more self-evident proposition, than that, in every Government, the majority must rule, and their will be uniformly obeyed. Now, if the majority enact a wicked law, and the Judge refuses to enforce it, which is to yield, the Judge, or the majority? Of course, the first. On any other supposition, Government is impossible.

In contrast to the self-educated Spooner, who hailed from rural Athol, Massachusetts, and read for the bar in Worcester (albeit with two distinguished Massachusetts lawyers and statesman: John Davis and Charles Allen), the Harvard-educated Phillips was a student of Joseph Story. Phillips' positivism fit squarely with Story's willingness in Prigg v. Pennsylvania ${ }^{31}$ to enforce the Fugitive Slave Act well beyond that which was required by the text of the Fugitive Slave Clause in Article IV. ${ }^{32}$ Story's stance was simply the obverse of Phillips. Whereas Philips and Garrison concluded that because the Constitution sanctioned slavery, it was a "covenant with death and an agreement with hell", Story considered himself bound by the positive law, apparently

${ }^{27}$ United States v. Fisher, 6 U.S. (2 Cranch) 358, 390 (1805).

${ }^{28}$ LySANDER SPOONER, THE UNCONSTITUTIONALiTy OF SLAVERY 58-59 (rev. ed. 1860), reprinted in 4 The Collected Works of LySANDER SpOONer: ANTI-SlaVery Writings (Charles Shively ed., photo. reprint 1971).

${ }^{29}$ Id. at $17-18$.

${ }^{30}$ WENDELl PHILLIPS, REVIEW OF LYSANDER SPOONER'S ESSAY ON THE UNCONSTITUTIONALITY OF SlaVery 10 (Boston, Andrews \& Prentis 1847) (Arno Press, photo. reprint 1969); see also id. at $8 \mathrm{n}$.* (citing 1 John Austin, Lectures On JuRISPRUdENCE OR THE PHILOSOPHY OF POSITIVE LAW (Robert Campbell ed., London, John Murray 3d ed. 1869)).

3141 U.S. (16 Pet.) 539 (1842).

${ }^{32}$ See U.S. CONST. art. IV, § 2 ("No Person held to Service or Labour in one State, under the Laws thereof, escaping into another, shall, in Consequence of any Law or Regulation therein, be discharged from such Service or Labour, but shall be delivered up on Claim of the Party to whom Service or Labour may be due.").

${ }^{33}$ William Lloyd GARRISON, RESOlution AdOpted By THE ANTISLAVERY SOCIETy (Jan. 27, 1843), reprinted in JOHN BARTLETT, FAMILIAR QUOTATIONS 663 (10th ed. 1919). 
even where the Fugitive Slave Act went beyond the injunction of Article IV. Likewise, Phillips' vociferous argument that the Constitution was a "pro-slavery document" ${ }^{34}$-in the publication that initially provoked Spooner to write his book-was adopted in its entirety by Chief Justice Taney in Dred Scott.

Whether the felt need to uphold slavery to preserve the Union motivated the positivist turn in the judiciary, or whether that turn had previously been implanted by Blackstonian views of sovereignty accepted by Federalists in pursuit of broad national power, I do not know. According to Cover, the tragedy of all this was that opinions about the proper role of judges were still fluid enough going into the 1940s that a natural rights approach was still possible. ${ }^{35}$ But judges instead took to positivism as their response to attacks on the injustice of slavery, and this view of the role of judges remains with us to this day, causing many to be hostile to the judicial protection of unenumerated rights.

\section{THE UNCERTAINTY OF IDENTIFYING UNENUMERATED RIGHTS}

In addition to the view of judging that stems from Blackstonian views of sovereignty and Austinian views of positivism, there is another reason why some are afraid of the judicial enforcement of unenumerated rights: they fear that the content of unenumerated rights is too uncertain and contestable to be enforced by courts. This concern too was expressed in Iredell's concurrence in Calder.

The ideas of natural justice are regulated by no fixed standard: the ablest and the purest men have differed upon the subject; and all that the Court could properly say, in such an event, would be, that the Legislature (possessed of an equal right of opinion) had passed an act which, in the opinion of the judges, was inconsistent with the abstract principles of natural justice.

I suspect that this, even more than concerns with sovereignty and a positivist conception of law, largely explains why the protection of unenumerated rights remains so controversial.

According to this concern, judges should do only what they are qualified to do and that is to enforce "the rule laid down." They have no particular expertise to identify fundamental rights, the content of which is not provided to them by an authoritative source. As Robert Bork put the matter: "[L]egal reasoning must begin with a body of

\footnotetext{
${ }^{34}$ See Wendell Phillips, The Constitution: A Pro-Slavery Compact: Selections From THE MADISON PAPERS, ETC. 3-7 (photo. reprint 1969) (N.Y. City, Am. Anti-Slavery Soc'y 1844) (summarizing the pro-slavery characteristics of the Constitution).

${ }^{35}$ See generally COVER, supra note 26, at 8-30 (describing how the tradition of positivism created the foundation for the notion that judges should be will-less).

${ }^{36}$ Calder v. Bull, 3 U.S. (3 Dall.) 386, 399 (1798) (Iredell, J., concurring).
} 
rules or principles or major premises that are independent of the judge's preferences." ${ }^{37}$ The process of identifying the content of unenumerated rights appears to be indistinguishable as a practical matter from adopting a judge's personal preferences. As Justice Scalia wrote: "when one does not have a solid textual anchor or an established social norm from which to derive the general rule, its pronouncement appears uncomfortably like legislation." ${ }^{38}$

It is a bit difficult to separate completely the uncertainty of unenumerated rights from the concepts of positivism or sovereignty. If the identification of unenumerated rights involves a choice unguided by the text of the Constitution, then why does this choice properly reside in the judiciary as opposed to the legislature? In other words, what gives courts the authority to enforce rights not specified in the text of the Constitution? As Robert Bork argued, if courts can simply reach the right results unconstrained or unguided by pre-existing law, then:

What can he say of a Court that does not share his politics or his morality? What can an admirer of the Warren Court say if the Supreme Court should become dominated by conservative activists? What can he say of the Taney Court's Dred Scott decision? He cannot say that the decision was the exercise of an illegitimate power because he has already conceded that power. There seems nothing he can say except that the Court is politically wrong and that he is morally justified in evading its rulings whenever he can and overthrowing it if possible in order to replace it with a body that will produce results he likes. In his view, the Court has no legitimacy as a legal institution. ${ }^{39}$

He then offers this colorful challenge:

Why should the Court, a committee of nine lawyers, be the sole agent for overriding democratic outcomes? The man who prefers results to processes has no reason to say that the Court is more legitimate than any other institution capable of wielding power. If the Court will not agree with him, why not argue his case to some other group, say the Joint Chiefs of Staff, a body with a rather better means for enforcing its decisions? No answer exists. ${ }^{40}$

But there is an answer, and it lies in what it is that makes a constitution legitimate, as well as in the original meaning of the text of the U.S. Constitution.

${ }^{37}$ Robert H. Bork, The Tempting of America: The Political Seduction of the LaW 264-65 (1990).

${ }^{38}$ Antonin Scalia, The Rule of Law as a Law of Rules, 56 U. CHI. L. REv. 1175, 1185 (1989).

${ }^{39}$ BORK, supra note 37, at 265.

${ }^{40} I d$. 


\section{THE IMPERATIVE OF UNENUMERATED RIGHTS}

I hope I have made plausible the claim that, while some personsperhaps even most-may be afraid of unenumerated rights for practical reasons, others are afraid for reasons pertaining to political sovereignty or the proper role of the judiciary. Even the practical objections, however, are not unrelated to matters of political authority and the legitimacy of judicial review. So, before addressing the practical concerns directly it is necessary first to consider why, to be legitimate, a legal system needs somehow to protect unenumerated rights. For only if one accepts the imperative of protecting unenumerated rights does one have a compelling motivation to confront and overcome the practical difficulties of identifying and enforcing unenumerated rights.

The root of the problem is democratic rule itself. As political philosopher Jeffrey Reiman has observed:

[T] here is nothing inherently legitimating about the electoral process. If anything, the electoral process is the problem, not the solution....

$[\mathrm{T}]$ he policies that emerge from the electoral process will be imposed on the dissenting minority against its wishes. And then, rather than answering the question of legitimacy, this will raise the question with respect to those dissenters. Why are the exercises of power approved by the majority against the wishes of (and potentially prohibiting the desired actions of) the minority obligatory with respect to the minority? Why are such exercises of power not simply a matter of the majority tyrannizing the minority? ${ }^{41}$

Reiman then points in the direction of an answer to these questions:

These questions not only point up the error of taking electoral accountability as an independent source of legitimacy, they also suggest that it is mistaken to think of electoral accountability and constitutional provisions as alternative sources of legitimacy. Rather, the Constitution with its provision limiting the majority's ability to exercise power is the answer to the question of why decisions voted by a majority are binding on the minority who disagree. ${ }^{42}$

I would recast Reiman's point in terms of the rights retained by the people. A legal regime could be legitimate, and its commands binding, if those who are bound actually consented to its jurisdiction. Such is the case, I suggest, for all of us having consented to the rules of this conference, or of the University of Pennsylvania, so long as we remain here. But whatever you may think about the existence and import of such consent to governance, the U.S. Constitution-or any constitution for that matter-cannot claim the unanimous consent of

\footnotetext{
${ }^{41}$ Jeffrey Reiman, The Constitution, Rights, and the Conditions of Legitimacy, in CONSTITUTIONALISM: THE PHILOSOPHICAL DimENSION 127, 134 (Alan S. Rosenbaum ed., 1988). ${ }^{42} I d$.
} 
the governed. Its legitimacy, if legitimate it be, must derive from some other quality.

Elsewhere, I have offered a possible alternative source of legitimacy. ${ }^{43}$ If laws imposed on non-consenting persons are proper insofar as they do not violate their rights, then the affected persons cannot complain. And if these proper laws are also necessary to protect the rights of others, then the persons on whom they are imposed are duty-bound to obey these laws for the very same reason that they are bound to respect the rights of others. Rights, after all, entail correlative duties in others. Laws that are the means of protecting the rights of others may partake in these same duties. Or so it seems reasonable to contend.

In short, laws that respect the rights of those upon whom they are imposed and that are needed to protect the rights of others are binding regardless of whether they were consented to. On this account, a legal system is legitimate if it contains procedures that assure us that the laws enacted and enforced are of this rights-respecting and rightsprotecting nature. A constitution that lacks the unanimous consent of the people it governs could still be legitimate, therefore, if it includes procedures that respect and protect the rights retained by the people.

This is not to say that judicial review of legislation to see if it violates these rights is warranted a priori. Any set of procedures that provides this assurance would be enough (although the more reliably rights are respected and protected, the more legitimate is a nonconsensual legal regime). For example, if one concludes that the bare fact that laws are enacted by popularly-elected representatives of those who are allowed to vote is enough to assure that these laws are rights-respecting and rights-protecting, there would be no need for judicial review to ensure a respect for either enumerated or unenumerated rights. But Reiman reminds us of what the founding generation learned to their dismay: there is no assurance that a majority will not violate the rights of the minority. For that matter, there is no assurance that elected representatives will not violate the rights of the majority. Indeed, there is also no assurance that majorities might not be stampeded into endorsing policies that violate their own rights, as they later come to regret.

So the founders decided to protect the rights retained by the people by adopting a number of formal constraints. They created a system that included, inter alia, a divided legislature, a presidential veto of legislation subject to override by a supermajority of both legis-

\footnotetext{
43 See generally Randy E. Barnett, Constitutional Legitimacy, 103 COLUM. L. REV. 111 (2003) (arguing that a constitution is legitimate to the extent it establishes lawmaking procedures that adequately ensure the justice of its enacted laws).
} 
lative chambers, and a federal government of limited and enumerated powers. They then put this whole complex system in writing and established an independent judiciary with lifetime tenure and the power to interpret and enforce its terms.

To all of these structural features, they later added an express bill of rights either as "actual limitations" on the written delegated powers of Congress or "for greater caution." ence, that "by enumerating particular exceptions to the grant of power, it would disparage those rights which were not placed in that enumeration, and it might follow, by implication, that those rights which were not singled out, were intended to be assigned into the hands of the general government, and were consequently insecure," the Ninth Amendment was added to the list of enumerated rights. Much later in our history, this structural arrangement was fundamentally altered by an additional written protection of the unenumerated rights retained by the people from infringement by their state governments in the form of the Privileges or Immunities Clause of the Fourteenth Amendment. ${ }^{46}$

Once again, it does not automatically follow that judicial review to ensure that legislation does not infringe upon the rights retained by the people is absolutely necessary to protect the unenumerated rights, privileges, or immunities to which the Constitution expressly refers. Perhaps, even in the absence of judicial review, all these rights are sufficiently well protected by the political process to provide the assurance that nonconsensual legal regimes require to be legitimate. Or perhaps judicial review would cause more harm than good given the uncertainty surrounding the content of unenumerated rights. But if, as an empirical matter, one lacks faith in the reliability of the legislative process in protecting the rights of minorities, majorities, or mere individuals, and if one concludes that judicial protection of unenumerated rights can make things better rather than worse, then one would have the requisite will to enforce unenumerated rights, provided one had a practical way to do so.

In considering the practical difficulties with protecting unenumerated rights, one must also consider the serious practical difficulty of our current system of protecting only some, but not all unenumerated rights. Current Due Process Clause doctrine protects only those unenumerated rights that are deemed by the courts to be "funda-

\footnotetext{
${ }^{44}$ James Madison, Speech in Congress Proposing Constitutional Amendments (June 8, 1789), in 12 The PAPERS Of JAMEs MADISON 196, 202 (Charles F. Hobson \& Robert A. Rutland eds., 1979).

${ }^{45} I d$. at 206.

${ }^{46}$ See U.S. CONST. amend. XIV, § 1 ("No State shall make or enforce any law which shall abridge the privileges or immunities of citizens of the United States ....").
} 
mental" and leaves unprotected those rights that are deemed by the courts to be mere "liberty interests." This doctrine, then, requires an extra analytic step by courts. Not only must they identify what are the rights retained by the people, they must also make the additional contestable distinction between those rights that are fundamental and those that are not. If courts are incompetent to identify the background rights retained by the people, they surely seem incompetent squared in trying to distinguish which of these allegedly indefinite rights are more important than others. And what gives them the authority to make this sort of judgment?

Moreover, courts now purport to make this distinction between fundamental rights and mere liberty interests by assessing whether a particular claim of right is "implicit in the concept of ordered liberty" or "deeply rooted in the nation's tradition and history." I say "purport to do so" because the results of any such analysis depend entirely on how a court chooses to define the rights at issue. If you ask whether the rights to preserve one's life or to avoid needless pain and suffering are implicit in the concept of ordered liberty or deeply rooted in the nation's tradition and history you get one result. If you ask whether the same can be said about the right to smoke cannabis for medical purposes you get the opposite result.

Yet both formulations accurately describe the conduct at issue. They merely describe the conduct at two different levels of generality. Since both characterizations are descriptively accurate, but each leads to an opposite outcome, a court may usually reach any result it wishes merely by choosing one of these two accurate descriptions of the right being claimed. To a large extent, therefore, present doctrine leaves the matter of protecting "fundamental" rights entirely to the fiat of judges.

There are two obvious ways to avoid this serious practical problem: one can deny protection to all unenumerated rights, a stance that has never been accepted in our constitutional history, or one can protect all the rights retained by the people equally. While the latter alternative would necessitate the identification of these unenumerated rights, it would avoid the additional and highly contestable step of discriminating among these rights. Plus, as we shall see in the next section, once one realizes what judicial protection of rights really entails, the pressure to identify them with great specificity is greatly reduced.

\footnotetext{
${ }^{47}$ See Washington v. Glucksberg, 521 U.S. 702, 720-21 (1996) ("[T] he Due Process Clause specially protects those fundamental rights and liberties which are, objectively, 'deeply rooted in this Nation's history and tradition,' and 'implicit in the concept of ordered liberty,' such that 'neither liberty nor justice would exist if they were sacrificed."') (citations omitted).
} 


\section{ENFORCING UNENUMERATED RIGHTS WITHOUT FEAR (OR FAVOR)}

Once one accepts the imperative of protecting unenumerated rights to the legitimacy of a constitution, the only remaining obstacle is the practical one of how to do so given their contestable content. The key to overcoming this alleged difficulty is to realize the following: The underlying source of this fear has less to do with the impracticality of identifying unenumerated rights than it does the perceived consequences of doing so.

For example, if a right protected by the Constitution is "absolute"-that is, not subject to regulation of any kind-then the practical implications of protecting all but a handful of fundamental rights would be enormous. If all liberty was protected equally, regulation would cease and, with it, most government functions-even government functions clearly authorized by the U.S. Constitution. With this "absolute" notion of constitutional rights in mind, it is easy to see how some would fear enforcing any but a small handful of rights, whether enumerated or not. Those holding this conception of constitutional rights would want either to limit sharply the rights protected by the courts to those that are really "fundamental" or eliminate judicial rights protection altogether, trusting instead to the judgment of majoritarian decision making.

In other words, the stakes involved in determining the exact content of unenumerated rights is raised enormously if one believes that the consequences of judicially protecting such a right is so momentous. If, on the other hand, the "cost" of judicially protecting constitutional rights was much lower, then we could tolerate considerably more uncertainty in identifying unenumerated ones. Given this insight, it is worth noting that, for better or worse, we do not now protect even enumerated fundamental rights absolutely.

Take the rights of freedom of speech and assembly. Under current law, wrongful exercises of speech in the form of fraud and defamation are completely unprotected. ${ }^{48}$ The "right" of freedom of speech does not even apply to these forms of verbal communication that we otherwise would call "speech." Prohibiting altogether this type of speech is considered completely unproblematic. Also under current First Amendment doctrine, the right of peaceable assembly can constitutionally be subject to reasonable time, place, and manner regulations of its exercise. ${ }^{4}$ In order to protest legally in the streets,

${ }^{48}$ See, e.g., Laurence H. Tribe, American Constitutional LaW § 12-12, at 861 (2d ed. 1988) ("[L]ibelous speech was long regarded as a form of personal assault, and it was accordingly assumed that government could vindicate the individual's right to enjoyment of his good name, no less than his bodily integrity, without running afoul of the Constitution.").

${ }^{49}$ See id. at 794 (discussing time, place, or manner regulation). 
for example, you can be required to obtain a parade permit. ${ }^{50}$ Provided the scheme of regulation is not designed to unduly burden the exercise of this right, or especially burden some viewpoints or benefit others, it is entirely constitutional.

So what does it actually mean in practice to protect a right as "fundamental" and subject legislation affecting such a right to "strict scrutiny"? In the main, it means ensuring: (1) that only wrongful speech that violates the equal rights of others is prohibited; and (2) that the exercise of rightful speech is not unduly burdened. A legal restriction is an undue burden when it is either not needed to protect the liberties of others, such as the liberty to use the streets and parks unimpeded by protesters, or when it is used against the rights of some because of their views. ${ }^{51}$

I realize that this summary greatly oversimplifies the complexity of laws regulating and banning speech and assembly, but does it not capture the heart of what our current approach is attempting to accomplish? Allow the "legitimate" exercise of these rights, and therefore exclude such wrongful acts as fraud and defamation, while mitigating the affect of these rights on the liberties of others by regulating the time, place and manner of their exercise.

Of course, this approach leaves much to be debated. Is pornography "wrongful" like fraud or defamation, or rightful and subject only to reasonable regulation? What constitutes an interference with the liberties of others sufficient to justify a regulation? Answers to these and other such questions are highly contextual and cannot be formulated in the abstract.

I ask you now to accept for the sake of argument this idealization of constitutional rights protection according to which wrongful acts (like fraud and defamation) can constitutionally be prohibited while rightful exercises of liberty can be regulated, provided that such regulation is warranted to protect the liberties of others. How might this approach reduce the fear of enforcing unenumerated rights?

Most obviously, by reducing the cost to governance of recognizing a right as judicially protected, such a scheme reduces the pressure to limit enforcement to just those liberties deemed by some to be fundamental. If all liberty may constitutionally be regulated, and only wrongful acts prohibited, then the recognition of a wide range of lib-

\footnotetext{
50 See generally JOHN E. NOWAK \& RonAld D. RotundA, CONSTITUTIONAL LAW § 16.46, at 1315-16 (7th ed. 2004) (discussing the Supreme Court's jurisprudence concerning parade permit cases).

51 See TRIBE, supra note 48, at 794 ("Government may be deemed to have 'abridged' speech ... if on its face a governmental action is targeted at ideas or information that government seeks to suppress, or if a governmental action neutral on its face was motivated by ... an intent to single out constitutionally protected speech for control or penalty.") (citations omitted).
} 
erties as constitutionally protected does not threaten all government regulation.

The judicial protection of liberties of any and all kinds would require that two questions be asked about any particular law affecting liberty: First, if a law prohibits conduct, is that conduct wrongful in the sense that it violates the rights of others, as does murder, rape, robbery, etc? If so the prohibition is constitutional. If the conduct is not, in itself, necessarily rights-violating, then it may not be prohibited, but it may still be regulated.

Second, if the conduct is rightful, in the sense that it does not necessarily violate the rights of others, then is a regulation of its exercise needed to protect the rights of others from risks associated with its exercise? Think about driving regulations that permit, but regulate, the manner of operating motor vehicles. Such regulations would be permissible, provided they were not shown to unduly burden the right because the government disapproves of its exercise or because the restriction is unreasonable.

Relevant to the assessment of whether a regulation is unreasonable would be whether its adoption was promoted or influenced by interest groups or factions who either disapprove of the conduct as "immoral" (or some euphemism for immoral) or who wish to benefit economically by restricting its exercise by potential competitors. As examples of the former, think of those who think the automobile is the scourge of the earth, or who oppose eating meat. ${ }^{52}$ As examples of the latter, think of local wine retailers lobbying for the prohibition of direct on-line sales by out-of-state wineries, or conventional beauticians lobbying for restrictions on hair-braiding shops.

So, if all liberty may be reasonably regulated and only wrongful acts that violate the rights of others can be prohibited, then the prospect of deeming any particular liberty to be constitutionally protected, while far from unproblematic, becomes much less scary. With any particular law, the judicial inquiry would shift from discerning the content of a particular unenumerated right to whether the regulation can be justified as necessary to protect the rights of others. If the law prohibits particular conduct altogether, the inquiry would be whether the prohibited acts necessarily or invariably violate the rights of others.

Would this put an end to all controversies or disputes concerning regulations? Of course not. Would it greatly increase the amount of litigation concerning the constitutionality of laws? Certainly it would, at least at first. Eventually, however, we could expect considerations of the wrongfulness of acts, or the necessity of regulations, to be in-

\footnotetext{
${ }^{52}$ Of course, these activists are free to contend that such laws $d o$ violate the rights of others, as they often do, in which case their claims must be considered carefully.
} 
ternalized by the law-making branches, which would greatly improve the chances of laws passing meaningful scrutiny, and reduce the success rate of challenges.

I do not think it is unrealistic to hope for a return to the days when Congress actually debated in a serious manner whether a proposed enactment was within or without its constitutional powers as it did when considering the first national bank. ${ }^{53}$ We see a glimmer of this where courts do protect such liberties as freedom of speech, press and assembly. While most legislators who consider these rights at all consider only whether the courts will uphold what they do, some actually reach their own independent conclusions on whether such acts really do interfere with these protected rights.

The approach I am recommending would still require courts to distinguish between rightful and wrongful conduct in order to uphold complete prohibitions of conduct, as opposed to regulations. Wrongful acts, as I have defined them, are those that inherently violate the rights of others. Some may reject this definition as overly restrictive. We can debate this another time. Others who accept the distinction, at least for the sake of argument, might still question the competency of courts to make such a distinction. But this is far less problematic than it may at first appear.

For one thing, courts would not have to start from scratch. We have a very long tradition of deeming some actions to be wrongful, such as murder, rape, robbery, burglary, theft-all the crimes I became a state court prosecutor to prosecute. While this tradition is not infallible, it is as good a baseline as any from which to depart. We must also remember that rightful activity is traditionally and routinely distinguished from wrongful activity by the law governing property, contracts and torts. So what is really being claimed is that, unless private conduct can be characterized as a trespass, tort, or breach of contract, it is privileged in the sense that it may only be regulated reasonably and not prohibited altogether. While some might claim that this proposal would require judges to be philosopher kings, it would be more accurate to view judges as accomplished first-year law students who know their private law subjects.

\section{CONCLUSION}

Assuming the idea of protecting unenumerated rights no longer seems so frightening, what warrant is there in the Constitution for doing so? You already know the answer to this. The original meaning

\footnotetext{
53 See generally Legislative AND DOCUMENTARY History OF THE BANK OF THE UNITED STATES 15-85 (M. St. Clair Clarke \& D.A. Hall eds., Washington, D.C., Gales \& Seaton 1832) (detailing the discussion on the constitutionality of the Bank of the United States).
} 
of the Ninth Amendment mandates that unenumerated rights are to be treated no less well-neither denied or disparaged-than enumerated rights, and we have already seen how enumerated rights may be regulated, and wrongful acts prohibited. The original meaning of the Privileges or Immunities Clause of the Fourteenth Amendment creates the same mandate for laws enacted and enforced by state governments. The evidence I have examined elsewhere shows that by "rights... retained by the people" the Ninth Amendment meant natural liberty rights, while the "privileges" or "immunities" to which the Fourteenth Amendment refers includes these natural liberty rights and the additional positive individual rights contained in the Bill of Rights. ${ }^{54}$

The original meaning of natural rights included all liberties, and was routinely summarized as the liberty to acquire, use, enjoy and dispose of property. ${ }^{55}$ This would also include the property, Locke maintained, that persons have in their bodies. ${ }^{56}$ In short, it is the right to use what is yours as you see fit or what today would be referred to as "liberty interests." This liberty is bounded by the equal liberties of others, so it is not liberty but license to violate the rights of others. While unquestionably capacious, this conception of rights excludes the right to demand things from others who have not themselves violated any rights-what today would be called "welfare rights." This is not to say, however, that the federal or state constitutions do not protect positive rights, because they do. "Nor is it to deny that government may create welfare rights or "entitlements" schemes at its discretion. This is only to say that the unenumerated natural rights to which the Ninth and Fourteenth Amendment refer are liberty rights.

The principal difference between the scrutiny of state and federal laws lies not in these textual protections of unenumerated liberties, but in the nature of the justification that is properly offered on behalf of prohibitions and regulations. To be proper, the federal government must be pursuing an object listed in Article I, Section 8 (or in one of the amendments), while the states must be properly exercising their general police power. Elsewhere, I provide an approach to the

\footnotetext{
${ }^{54}$ See RAndy E. Barnett, Restoring the Lost Constitution 53-86 (2004) (explaining this conclusion at length).

${ }^{55}$ See id. at 257 (noting that some scholars view these rights as the appropriate formulation of natural rights).

${ }^{56}$ See John Locke, Two Treatises OF GOVERnMENT AND A LeTter CONCERning TOLERATION 111 (Ian Shapiro ed., Yale Univ. Press 2003) (1690) ("[E]very Man has Property in his own Person ....") (emphasis added).

${ }^{57}$ See BARNETT, supra note 54, at 236-37 (identifying protections of positive rights in state constitutions).
} 
police power ${ }^{58}$ that is largely based on the Lockean approach developed by treatise-authors Thomas Cooley ${ }^{59}$ and Christopher Tiedeman. $^{60}$ I cannot resist noting here, however, that the so-called police power is itself unenumerated, and the uncertainty of this nontextual power has not stopped it from being invoked by courts, and even by those who resist enforcing unenumerated rights because of their uncertain content. Why? Because of their views of "sovereignty" of course.

In the end, for those who respect the text of the Constitution, as well as its original meaning, the protection of unenumerated rights is simply not optional. To disregard the unenumerated rights provisions because they do not conform to one's conception of the Rule of Law is as objectionable as discarding the enumerated powers scheme because it does not conform to one's conception of Justice. Both approaches put one's own visions above that of the written Constitution. Some may even call this "judicial activism," though I continue to resist using that largely vacuous pejorative term. ${ }^{61}$ In this essay, I hope I have shown why, whatever else might justify setting the text of the Constitution aside, it cannot be the claim that we should be afraid of the unenumerated rights to which that text refers.

\footnotetext{
${ }^{58}$ See Randy E. Barnett, The Proper Scope of the Police Power, 79 Notre Dame L. REV. 429, 430 (2004) ("[T]he police power of states includes the power to prohibit wrongful and to regulate rightful conduct of individuals.").

${ }^{59}$ See generally ThOMAs M. COOley, A TREatise on the CONSTitutional Limitations Which Rest UpOn the Legislative Power of the States of the American Union (Boston, Little, Brown \& Co. 1868) (describing Cooley's interpretation of the police power).

${ }^{60}$ See also BARNETT, supra note 54, at 323-31 (discussing the views of Cooley and Tiedeman). See generally Christopher G. Tiedeman, A Treatise on the Limitations of Police Power in THE UNITED STATES (St. Louis, F.H. Thomas 1886) (photo. reprint ed. 2001) (laying out Tiedeman's view of police power).

${ }^{61}$ See Randy E. Barnett, Is the Rehnquist Court an "Activist" Court? The Commerce Clause Cases, 73 U. COLO. L. REV. 1275, 1275-81 (2002) (discussing the meaning of "judicial activism").
} 